\title{
Autonomy and Regulation in the School System in England
}

\author{
Philip A. Woods, Amanda Roberts, Joy Jarvis, Suzanne Culshaw ${ }^{1}$ \\ University of Hertfordshire, UK
}

\begin{abstract}
A chapter in
Olof Johansson \& Helene Ärlestig (eds), Educational Authorities and Schools:

Organisation and Impact in 20 States, Springer.
\end{abstract}

Key words: self-improving system; school-led improvement; governance; academies; ethical autonomy

\begin{abstract}
The chapter examines the school system in England, concentrating on developments since 2010. During this period, a radical refashioning of the school system in England has taken place as large numbers of schools have moved from being the responsibility of local authorities to becoming 'independent', though still state-funded, academies operating in the framework of and accountable to national authorities. The chapter explores the claimed institutional and professional autonomy integral to the idea of a selfimproving school-led system influential in the national policy driving this change.

Different ways of understanding autonomy are examined through notions of licensed, conditional, regulated, rational and ethical autonomy, contributing to a critical understanding of how the system is developing. The chapter highlights, inter alia, the importance of examining critically the distribution of autonomy across the various actors and institutions in the system. It also highlights the ethics of autonomy. The latter brings to the fore the moral demands entailed in autonomy and the importance and challenges of exercising principled autonomy and critical reflexivity as an integral feature of autonomous practice, especially in the context of pressures in the school system to conform to performative and competitive logics.
\end{abstract}

[191 words]

\footnotetext{
${ }^{1}$ Corresponding author: Professor Philip Woods, p.a.woods@herts.ac.uk
} 


\section{INTRODUCTION}

This chapter explores the autonomy that is intended to characterise the school system in England. Authorities with national responsibilities for schools are placed in the context of the governance system in which they operate, paying particular attention to the claimed institutional and professional autonomy that is integral to the 'overarching narrative' of a 'self-improving school-led system' for policy on schools since 2010 (Greany and Higham 2018: 10). Autonomy implies the possession of a significant degree of freedom by a person or an institution to decide how to conduct themselves. It can be contrasted with regulation, where rules or directives determine conduct. The chapter provides an overview of the school system in England, concentrating on how it has developed since 2010, and explores meanings of autonomy as a way of contributing to a critical understanding of how the system is developing.

\section{ENGLAND'S SCHOOL SYSTEM SINCE 2010}

Responsibility for the school system in England rests with the Department for Education (DfE), a department of the UK government which shapes and regulates the school system through non-ministerial departments and agencies that have national responsibilities. The main national authorities are set out in Table $1^{2}$.

${ }^{2}$ Further details available at https://www.gov.uk/government/organisations 


\begin{tabular}{|c|c|}
\hline $\begin{array}{l}\text { The Office for Standards in } \\
\text { Education, Children's } \\
\text { Services and Skills (Ofsted) }\end{array}$ & $\begin{array}{l}\text { inspects and regulates schools and other services that care for children and } \\
\text { young people and provide education and skills for learners of all ages; } \\
\text { reports to Parliament, rather than the Secretary of State for Education } \\
\text { directly, but its statutory powers and duties reflect the policies of central } \\
\text { government }\end{array}$ \\
\hline $\begin{array}{l}\text { The Office of Qualifications } \\
\text { and Examinations } \\
\text { Regulation (Ofqual) }\end{array}$ & regulates qualifications, examinations and assessments in England \\
\hline $\begin{array}{l}\text { Education and Skills } \\
\text { Funding Agency (ESFA) }\end{array}$ & $\begin{array}{l}\text { brings together the former responsibilities of the Education Funding Agency } \\
\text { (EFA) and Skills Funding Agency (SFA) to create a single agency } \\
\text { accountable for funding education and skills for children, young people and } \\
\text { adults }\end{array}$ \\
\hline $\begin{array}{l}\text { Standards and Testing } \\
\text { Agency (STA) }\end{array}$ & $\begin{array}{l}\text { responsible for providing a testing, assessment and moderation system to } \\
\text { measure and monitor pupils' progress through primary school from reception } \\
\text { to the end of key stage } 2 \text { (age 11), developing and delivering the professional } \\
\text { skills test for trainee teachers and managing the general qualifications } \\
\text { logistics service provided to exam centres and examiners }\end{array}$ \\
\hline $\begin{array}{l}\text { The National Schools } \\
\text { Commissioner and regional } \\
\text { schools commissioners }\end{array}$ & $\begin{array}{l}\text { appointed by the Secretary of State for Education, responsible for supporting } \\
\text { school leaders, teachers and governors with the stated aim of achieving the } \\
\text { best education system possible for all children in England; works closely } \\
\text { with } 8 \text { regional schools commissioners who are accountable to the National } \\
\text { Schools Commissioner and each supported by a board of headteachers }\end{array}$ \\
\hline
\end{tabular}

Note: In 2018, the National College for Teaching and Leadership (NCTL) which had responsibility for improving academic standards by recruiting and developing a workforce to meet the needs of the school system, and to help schools to help each other to improve, was absorbed into the Department for Education.

\section{Table 1: School authorities with national responsibilities, 2018}

These authorities have to be placed in the context of the radical refashioning of the system that has taken place, especially since 2010. They are part of the intention to develop 'a self-improving school system' characterised by 'school-led improvement', which is a stated policy priority in the quest to raise standards of schooling on a sustainable basis (DfE 2016b: 20; original emphasis). Although the intensified reforms in the structure of English school education since 2010 cannot be said to have followed any blueprint of a self-improving system design, such as that set out by Hargreaves (2010), the idea of a 'self-improving school-led system' (SISS) is influential in English educational policy and this has led to SISS being described as an 'overarching narrative' for policy on schools (Greany and Higham 2018: 10). One of its consequences has been to further diminish the role of local authorities and to create a new kind of 'middle tier' which is continuing to evolve (Woods and Simkins 2014). In the following section, we summarise the key elements of SISS and examine the growth of 'independent' state schools, before turning to examine how the middle tier is evolving. 


\section{A self-improving school-led system}

The idea of a self-improving system denotes a system where the main, ongoing impetus to make the system better comes from learning and change generated within the system rather than prescriptions and commands that arise from outside the system. The building blocks of a self-improving system according to Hargreaves $(2010,2012)$ are four-fold.

First is the structural framework provided by 'family clusters' of schools that facilitate active collaboration, sharing of ideas and school improvement. The clusters are described as family-like to indicate 'an organic and sustainable relationship of a relatively small number of schools' (Hargreaves 2010: 6).

The second and third are cultural elements. The second element is taking a local solutions approach in which schools work together to examine problems and generate solutions. This involves 'breaking free from a dependency culture in which the solutions to school problems are thought to lie somewhere beyond the schools themselves' (p8). The third element is what Hargreaves refers to as co-construction. This is about working together so as to agree the problem and the task to be tackled and the priorities, to co-design the action and to implement change as a process of co-production. It involves not only schools but also educators and students working together and includes 'joint practice development' that fosters mutual professional development and practical change (Hargreaves 2012: 8). The notion of joint practice development goes back to research by Fielding et al (2005: 32) which found that professional learning was, instead of a transfer of practice, a developmental process of 'collaborative and affirming work' between teachers through which they and their practice grow. Collaboration such as this is the fundamental logic of the self-improving system and accords with what much research indicates about the benefits of collaborative learning within and between educators (Szegedi et al 2018, Woods and Roberts 2018).

The fourth element is system leadership which is exercised by people at all levels of the system. This highlights the significant impact of a commitment to and action supporting schools and students throughout the system and not just to one's own school.

Some of the spirit underpinning these elements can be seen in the articulation of government policy and its stance towards local authorities (LAs). LAs are elected councils responsible for the running of a range of local services. These services include school education, but government policy in recent years has resulted in large numbers of schools being removed from the responsibility of LAs to become 'independent' state schools (academies and free schools - explained below). The rationale for the reforms is that schools outside the responsibility of LAs - 'autonomous academies' (DfES 2016a: 
20) - give 'more freedom and autonomy to headteachers and leaders' (p3): the reforms 'set school leaders free' and leave behind 'stifling' and 'micromanaging' government (p10), thus 'empowering great teachers and leaders' ( $\mathrm{p} 55)$ and 'giving teachers professional autonomy over how to teach' (p89). A central role is given to 'supported autonomy' which means 'strengthening the infrastructure that supports all schools and their leaders to collaborate effectively' (DfE 2016a: 18) and which will enable 'the best headteachers to extend their influence beyond their own schools and help them to raise standards across the system' (p72). This kind of system leadership, undertaken by headteachers and including national leaders of education ${ }^{3}$, is seen as integral to the current system (DfE 2016b, Hill 2011). Headteachers have a crucial responsibility not only for the performance of their school, but also as key actors in system-wide improvement.

Since 2010, there has been a dramatic increase in the numbers of 'independent' state schools (Bolton 2015, Nerys 2017, House of Commons Education Committee 2017, National Audit Office 2018, West and Bailey 2013, Woods and Simkins 2014). Schools under the auspices of local authorities (LA-maintained schools) have changed their status to become academies. They have become either a sponsored academy (sponsored by businesses, faith groups, charities or educational institutions such as universities, further education colleges and 'successful' schools) or a converter academy (that has opted out of LA control but, as the school is deemed by government to be performing well, requires no sponsor). In addition, there are some new schools, designated as 'free schools', which are identical in legal status to academies. These are started and run by teachers, charities, parent groups, existing academy sponsors or other providers. By January 2018, almost three-quarters of secondary schools, and just over a quarter of primary schools, were academies (which includes more than 400 free schools) (National Audit Office 2018).

\section{An evolving middle tier}

The question of what is happening to the middle tier of governance (the governance structures between the national level and schools) in England's changing system is a crucial one. This middle tier is undergoing fundamental change, resulting in new patterns of governance (Woods and Roberts 2014, Woods and Simkins 2014). The power of LAs, which historically were responsible for school provision, has diminished since the 1980s. Since 2002, and at a faster rate since 2010, schools formerly under the auspices of LAs have become sponsored or converter academies. The Church of England and the

\footnotetext{
${ }^{3}$ https://www.gov.uk/guidance/national-leaders-of-education-a-guide-for-potential-applicants 5 of 23
} 
Catholic Church retain an important role in the state education system through their church schools and sponsorship of academies ${ }^{4}$.

A concern is that the middle tier is no longer providing the co-ordination needed by the school system, especially as there are competitive pressures on 'autonomous schools to act in their own interests' (Greany and Higham 2018: 25). Government policy continues to be committed to policies that 'stimulate competition' between schools (DfE 2016: 17), as well as collaboration. We next give a brief account of changes to LAs, and then turn to new ways of grouping schools that are developing.

\section{Local authorities}

The 150 LAs in England are described as having the strategic lead for education of children and young people and a legal duty to ensure that every child fulfils his or her educational potential ${ }^{5}$. From 2004, as part of a national policy to integrate children's services, LAs were required to appoint a Director of Children's Services (DCS), tasked with improving the well-being of all children and young people6. The DCS has professional responsibility for the leadership, strategy and effectiveness of the LA's children's services and is responsible for securing the provision of services which address the needs of all children and young people. This role involves leading a wide range of activities, people and agencies in local efforts to improve outcomes for all children and young people. A senior local government officer, the DCS provides a line of accountability for those working with young people, though this accountability is less clear as the local schools system becomes more plural and diverse. A particular focus of the role is to ensure that all children, including the disadvantaged and vulnerable, are championed. Contributing to the achievement of this agenda, the DCS leads the LA's management of central services such as place planning, admissions and school support services. A DCS also has responsibilities in relation to the quality of education in their local area.

In the current evolving school system, the powers of LAs are diminished in relation to schools (Wolf 2013). As noted above, the majority of secondary schools and over a quarter of primary schools are academies. LAs are therefore dependent on building relationships, negotiating, facilitating partnerships, and leading and engaging in local dialogues. As a consequence, many LAs are developing a new version of their old middle

\footnotetext{
4 http://www.catholiceducation.org.uk/about-us; https://www.churchofengland.org/more/education-and-schools/church-schools-andacademies\#na

${ }^{5}$ See https://www.local.gov.uk/topics/children-and-young-people/education-and-schools

${ }^{6}$ See https://www.gov.uk/government/publications/directors-of-childrens-services-roles-and-responsibilities 
tier role and creating new structures in order to focus on the provision of central support services. Many are, for example, negotiating partnerships and agreements with schools to provide support services, broker support between schools and work with schools in other ways. Greany and Higham (2018: 24) conclude that LAs have had to become part of a commercial middle tier. The values guiding the new models created by LAs are not necessarily entirely those of private business and competition. Some models are more entrepreneurial than others, operating at a greater organisational distance from the core work of the LA; others seek to be more co-operative and community-orientated, though tensions nevertheless exist with pressures for relations between schools and LAs to be 'based upon an economic contractual relationship that challenges traditional notions of public service' (Boyask 2015: 39).

\section{New ways of grouping schools}

The diverse ways in which schools group together is a key structural feature of the emerging governance system (Woods and Simkins 2014). New and changing forms by which schools are grouped are developing as schools leave LAs to become academies or, if they remain with LAs, reconfigure how they arrange support for school improvement. They are creating a complex and evolving middle tier alongside LAs. Because of this complexity, it is not possible to provide a comprehensive overview. We focus here on major examples of the kinds of school groups being formed: federations, teaching school alliances and academy chains.

The term 'federation' covers a range of collaborative relationships between schools (Chapman 2015). Federations can include both academies and LA-maintained schools. The opportunity to form federations was provided formally in 2002 when the Education Act of that year allowed for a group of two or more schools with a formal agreement to work together to raise standards. Such groups of schools can take the form of hard federations. These are legal entities, with a single governing body, that institutionalise the partnership between schools. There are also looser arrangements that give individual schools greater autonomy. These looser arrangements constitute soft federations or collaboratives - often referred to in schools as 'local clusters' (Greany and Higham 2018: 70) - where a group of schools has 'chosen to cooperate or share resources in areas such as continuing professional development or common services but without modifying their leadership or governance structures' (Woods and Simkins 2014: 332). The leaders of federations undertake some of the leadership roles traditionally associated with middle tier leadership, though not statutory roles based in the LA. This may include building collegiality across a number of schools, providing strategic leadership and managing cross-phase transition. Interpretation of guidance from central government and support for its implementation are also key roles which complement rather than replace the 
statutory roles based in LAs. Research by Greany \& Higham (2018) suggests that local clusters of schools are highly important to schools, with $67 \%$ of school leaders in primary schools and $40 \%$ in secondary schools describing their local cluster as their strongest partnership.

Teaching school alliances (TSAs) were introduced in 2011 (Gu et al 2015). In a TSA a group of schools is led by a designated teaching school that has responsibility for coordinating and providing initial teacher education, spreading 'excellent practice' and providing professional and leadership development across the alliance of schools ${ }^{7}$. There are over 500 TSAs (National College for Teaching and Leadership 2017). They do not operate in a uniform way. Greany and Higham's (2018) study found three forms emerging amongst the TSAs they studied: hierarchical, where 'powerful schools' take 'lead positions' and gain 'disproportionate influence' (p80); exclusive and internally equitable, where decision-making is shared by the member schools but local schools wanting to join are not admitted, in order to keep the alliance small; marketised, where the alliance is a loose affiliation focused on 'selling short-term support services to predominantly external "client" schools' (p82).

Academy chains, also referred to as 'umbrella trusts' (West and Wolfe 2018), are another highly significant innovation. The first academy chain came into being in 2004, since when the number of such chains has risen rapidly (National Audit Office 2018). Most academies are in multi-academy trusts (MATs), where a group of schools is governed through a single set of trust members and directors ${ }^{8}$ and the MAT is expected to support school-led improvement (DfE 2016a). By 2016 there were 1,121 MATs and 65\% of all academies and free schools were in MATs (House of Commons Education Committee 2017, Nerys 2015). By 2018, over 70\% of academies were run by MATs. The official intention is that 'in five to six years a "tipping point" will be reached where most schools have converted [to academy status outside LA control] and joined a MAT' (House of Commons Education Committee 2017). A MAT is a single legal entity. Individual schools within a MAT do not exist as legally separate institutions, but are 'local sites through which the MAT delivers' (West and Wolfe 2018: 16). This is very different from LAmaintained schools which have a governing body that is a 'free-standing legal entity' and whose composition is set by statute and minutes are open to public scrutiny (p23). Such a fundamental change in school status would appear to be revolutionary as it does away with the statutory basis that assures the institutional existence of the key building block of the English school system. Its implications have hardly been debated and certainly not fully examined and researched.

\footnotetext{
${ }^{7}$ https://www.gov.uk/guidance/teaching-schools-a-guide-for-potential-applicants\#teaching-school-alliances

8 http://apps.nationalcollege.org.uk/resources/modules/academies/academies-online-resource/ac-s4/ac-s4-t1.html 8 of 23
} 


\section{AUTONOMY}

We turn now to autonomy. The capacity of schools to generate solutions and to break free of dependency on outside solution-providers is an essential element of Hargreaves' (2010) conception of a self-improving system, and requires a significant degree of autonomy for schools. It also requires autonomy for educators that enables 'the exercise of individual choice and creativity', albeit within 'strong agreements' on certain norms of practice, such as an expectation of professional development by all teachers on priority areas for the school (Hargreaves 2014: 705). As we have seen above, the Government attaches great value to schools, school leaders and teachers exercising autonomy within the school system. Our purpose in this section is to explore the notion of autonomy and its meanings and conditions as a contribution to reflecting critically on the English school system.

Autonomy is the condition in which a person or an entity, such as a country or organisation, can exercise self-rule or self-governance. There is a 'lack of coercion, and ability to act free from the prescriptions of others and of convention' (Baggini 2015: 101). Many conceptions of what autonomy means can be found in academic literature (O'Neill 2003: 2). At its simplest, autonomy could be described as 'latitude for discretionary judgement' (Lundström 2015). However, keeping close to the etymology of the word 'autonomy' (autos meaning self and nomos law), we take the basic meaning of autonomy to be the capability to adopt for oneself the principles, rules or values that guide one's action. These entail 'normative principles about what is worthwhile - that is, a conception, perhaps somewhat inchoate, about what makes a life well lived' (Brink 2003: 28). This implies that one has some justification for the authenticity of the motives and judgements in choosing such principles, rules or values - that is, that they are in some sense freely adopted on the basis of one's own rationale and not imposed. An implication is that autonomy consists of independent choosing that follows rational processes. Whilst such 'rational autonomy' is 'ultimately based on desires or preferences', there is some reasoned basis for the choice, for example a process that means the choice is 'well informed, or fully informed, or reflective, or reflectively endorsed' (O’Neill 2003: 5). This does not mean necessarily that the choice is ethically good. For example, a school leader may reason that their school needs to do $\mathrm{x}, \mathrm{y}$ and $\mathrm{z}$ to survive, or that the school's best interests lie in removing from the school roll ('off-rolling') pupils who will bring down the school's grades, or (conversely) that the school has to make inclusion its overriding priority. The fact that policy choices have been rationally thought through does not in itself make those choices ethical. We shall return to the issue of ethics and autonomy below. 
From the basic position on autonomy, as the capability to adopt for oneself the principles, rules or values that guide one's action, we examine some of the features that affect the practice of autonomy and help us understand its operation in a school system intended to be infused by autonomy, such as that in England. The descriptions of autonomy discussed here (licensed, regulated, conditional and so on) do not denote discrete types of autonomy: rather, they highlight different ways in which autonomy is constructed and experienced in practice and sometimes by design. One or more of these descriptions may be appropriate depending on the context and experience of autonomy.

Educational and other public services have procedures for giving autonomy and signalling that it is legitimate. Licensed autonomy refers to the granting of autonomy as a professional which is signified in gaining an appropriate licence (Apple 2007, Lundström 2015). The notion can be applied equally to institutions. In the English school system, academy schools can be seen as being granted licensed autonomy by virtue of their academy status. They are thus afforded autonomies that other institutions do not have, creating a hierarchical distinction between institutions. Below, we will discuss the significance of hierarchical distinctions further in relation to the conditional features of autonomy.

A question in relation to any apparent state of autonomy is the degree to which the autonomy is genuine. Licensed autonomy may be regulated by the powers to which the professional educator or institution is held accountable and which sets the framework and the discourse within which autonomous practice takes place. Table 1 showed the main authorities with national responsibilities for schools that impinge upon autonomy in England. They do this by determining and operating processes that significantly affect the work of schools and educators, such as school inspections, systems assessing pupils' progress and achievement and oversight of academies. Greany and Higham (2018: 23) argue that the system in England since 2010 involves significant 're-regulation', with 'new curriculum requirements, central funding contracts, performance indicators and new forms of intervention, including powers for Regional School Commissioners [see Table 1] to intervene in academies and schools judged as "inadequate" or "coasting". A significant degree of compulsion could be seen in the government's notion of 'supported autonomy' - autonomy 'supported by fair, stretching accountability measures; and enabling pupils, parents, and communities to demand more from their schools' (DfE 2016a: 8 - emphases added)

Critics of claims that schools and educators have greater autonomy also point to the power of the dominant policy discourse to create pressures to conform to the kinds of professional and educational values preferred by those in powerful policy positions. For example, a strong discourse valuing enterprise arguably helps to instil in school leaders 
aspirations to entrepreneurial leadership informed by private business and competitive values (Woods 2013). To the extent that this is unthought through and unreflected upon by school leaders and hence the result of 'coercive persuasion' (Stacey 2012: 80), any autonomy they are exercising does not involve genuinely free choices.

In a context of tight regulation and coercive discourse, licensed autonomy might be appropriately seen as regulated autonomy (Apple 2007, Lundström 2015). The key thing with regulated autonomy is that the person or institution has taken on a purpose and principles through compulsion or without reflecting on the strong factors influencing their feelings and thinking. In essence, it is not really autonomy. For Apple (2007) and Lundström (2015), regulated autonomy is a specific kind of distortion of professional autonomy. The latter is licensed and framed in such a way that autonomous practice is not the result of independent choices but of professional identities and values that conform to performative and competitive logics. From a critical perspective, powerful economic actors in a capitalist society are part of a social context that contributes to the regulation of autonomy, through their influence on dominant views on schooling and thereby the content and aims of school education (Murphy 1982).

In practice, even if autonomy is only minimally regulated in the sense just described, there are always significant constraints. Autonomy is always conditional autonomy. That is, autonomy is affected by a range of factors, to do with resources, opportunities, relationships and so on. These include processes of accountability for decisions and practices autonomously determined. Many factors will constrain autonomy, but others will enable autonomy. This allows us to construct a simple analytical scheme to compare differing circumstances. The first case is what we refer to as positive conditional autonomy. This is where the enabling conditions are greater or more important than the constraining conditions. In this instance, the conditions tend to support autonomy. The second case is what we refer to as negative conditional autonomy. This is where the constraining conditions are greater or more important than the enabling conditions. In this instance, the conditions tend to limit autonomy, but do not negate the essence of autonomy in the way that the policy frameworks and persuasive policy discourses do in regulated autonomy. Negative conditional autonomy makes autonomy harder but not impossible. In complex conditions, 'there may still be latitude for teacher autonomy even within an overall trend towards reduced autonomy' (Lundström 2015: 74).

It is worth exploring further the point about taking advantage of any latitude and of the possibilities for creating latitude. The conditions affecting autonomy are not only external (the cultural context, social structures and policies that schools and educators work within) but are internal too. The identity which individual teachers and groups of teachers hold is one example of such internal conditions. This is exemplified by the practice of 
teachers within the HertsCam Network ${ }^{9}$. Within the network, teachers are supported in becoming autonomous professionals through undertaking teacher-led development work based on individual values and concerns. Membership of the network helps to sustain a professional identity as teachers who are intent on taking a pro-active role in the development of both policy and practice and the building of professional knowledge (Woods et al., 2016). This process exemplifies Wenger's (1998) argument concerning the deep connection between identity and practice development.

As we noted above, the exercise of genuine autonomy, under however positive conditions, does not mean that the autonomous choices and practice are ethical. Yet autonomy can only be justified or have worth if it is advancing purposes with moral value. Professional responsibility entails attention to ethical questions and in contemporary times arguably this attention is in need of 'reviving' within professions (Solbrekke and Sugrue 2011:20). What then is involved in ethical autonomy - that is, independent choosing that leads to ethically justified choices? The validity or soundness of the source of justification is key here. O'Neill (2003) provides some interesting reflections on this as he examines autonomy in Kantian philosophy. He distinguishes between two kinds of justification. One is an arbitrary (unreasoned) choice to defer to a source of what is right, which could be the church, the 'edicts of rulers', subjective feelings of moral rightness or 'the will of the majority' (p9-10). He calls this heteronomous autonomy. We shall refer to it as dependent autonomy as it resonates with the philosophy of dependence which sees people as requiring to find the right rules, texts or leaders to follow in order to act ethically (Woods 2016, Woods \& Roberts 2018). Dependent, or heteronomous, autonomy is not really ethical in the Kantian perspective because the act of choosing to which moral guide to defer does not in itself establish that it is a valid source of ethical rightness. In education, appealing to the requirements of policy for example does not automatically make choices guided by those policy requirements ethical. It can be legitimately argued that educators funded by public money have some ethical duty to follow democratically legitimated policy decisions, but there are other ethical issues too that bear upon what is morally appropriate action in practice.

To return to O'Neill, the other option is Kantian or principled autonomy. From a Kantian view, choices to be ethical must have two features. One is that they are grounded in some kind of reasoning: they should not be based simply on enthusiasm or flights of fancy (O'Neill 2003: 14). We might add to this that they should not be based solely on the reasoning of a charismatic leader either. The second is that the principles that guide

\footnotetext{
9 The HertsCam Network is an independent teacher-led, not-for-profit organisation committed to educational transformation through support for teacher leadership. In both of its core programmes, facilitators are supported by principles and guidance on processes to support teachers in effecting change through the initiation, design and leadership of development projects, including a collection of tools which they can draw from and develop (Hill, 2014).
} 
the choices have to be followable by others and 'universal in scope' (p15). The principles guiding choices have to be something that you would expect to apply to all. This has a relevance in a school system that promotes autonomy amongst educators and schools: for example, principled autonomy encourages the asking of critical questions about, for example, policies followed by a school. An educator can ask, 'Would I commend these as policies that all schools should follow?'. Policies intended to off-roll pupils are particularly pertinent, as the passing on of pupils considered not to be conducive to the success of the school has implications for the rest of the system.

More widely, to what extent is systemic inequality of treatment being built into the system? There seems to be an implicit suggestion in some of the policy discourse that the weakest are to be removed rather than enabled to develop: the system is not designed to support those in challenging circumstances to overcome these challenges but instead to discover and eliminate weakness, allowing 'the best schools and leaders to extend their influence, taking over from weaker ones' (DfE, 2016a: 10). Some local policies seem to foster systemic inequalities. Schools less well-rated by Ofsted are excluded from some school partnerships for example (Greany and Higham 2018: 43). On the other hand, other local policies are aimed at reducing inter-school inequalities, such as the creation of fair access panels (p60). Solbrekke and Sugrue (2011: 18) suggest that assessing professionals on the basis of performance measures and market forces - the performative and competitive logics mentioned above - create conditions conducive to professionals such as educational leaders and teachers finding that '...their moral principles very often are compromised in order to meet the requirements of efficiency and external goals'.

Policies that lead to inequalities and divisions in these ways do not sit well with the idea of a democratic school system in which all are supported to achieve, no matter what their starting point, and a conviction that strength is collegial and held by education as a whole. Such collegiality would seem to be at the heart of a self-improving system that engages in continuous improvement through joint practice development, in contrast to conditions of competition and hierarchical structures that tend to encourage a restricted sense of professional responsibility that is 'loyal to the culture and prescriptions of the workplace rather than to the standards of the profession' (Solbrekke and Sugrue 2011: 15). Hargreaves' (2012) emphasis on the collective moral purpose articulates the imperative of the universal principle basic to principled autonomy. It entails a commitment by schools and educators to the value and learning of everyone. Ethical concern cannot justifiably stop at the school boundary, or indeed the boundary of the federation, TSA or MAT.

O'Neill (2003: 16) emphasises that principled autonomy entails a process that is reflexive: the question is not whether the person is autonomous in a principled way but 
whether the processes they follow involve reflexive thinking that asks challenging questions about the validity of the principles on which they base their choices. O'Neill's discussion reinforces the need to reflect upon and examine what justifies and guides action. If autonomy is to be principled, the creation and following of policies, nationally, locally and in schools, require examination of their principles from the viewpoint of whether they can be justified as actions that all can follow.

\section{IMPACT}

Assessing the effects of the school system as it has changed since 2010 is extremely difficult. The nature of the system is still unfolding, often in different ways locally (Greany and Higham 2018, Woods and Simkins 2014), and the various effects of such a complex system will take many years to play out. There is 'a lack of reliable information of the way in which the academies policy is working' (West and Wolfe 2018: 5). We do know, however, that whilst there are examples in the current system of positive change in learning experiences and achievement, it is not possible to conclude that the structural change introduced by academy status, as 'independent' state schools, and governance through MATs in itself ensures positive change generally: there are significant variations in the educational performance of academies and MATs 10 . Nor do reforms in England appear to be bringing about fundamental change in the direction of reducing inequalities and increasing social justice. There appears to be no significant reduction in the educational performance gap between the richest and poorest areas from the mid-1980s to the mid-2000s; and the educational experience of different social classes remains notably unequal ${ }^{11}$.

In the remainder of this section we concentrate on how we can better understand the avowed greater autonomy of the current system, using the analysis of autonomy in the previous section. One of the themes throughout this discussion is the importance of being aware of the distribution of autonomy. Autonomy, the ways in which it is regulated and the conditions of autonomy are distributed differently across different actors and institutions in the system. Hence the experience of autonomy is likely to differ.

It is clear that there are negative conditions affecting autonomy. On the basis of his research into reforms intended to introduce greater autonomy for teachers in Sweden, Lundström (2015) concluded that the reforms have reduced teachers to deliverers of 'goal

\footnotetext{
${ }^{10}$ For research and analysis concerning academies and MATs, see Academies Commission (2013); Andrews et al (2017); Her Majesty's Chief Inspector of Education, Children's Services and Skills (2017); PriceWaterhouseCoopers (2008).

11 For research and analysis concerning inequalities, see Clegg et al (2017); Gorard (2014, 2016); Lumby and Coleman (2016); Reay (2017).
} 
achievement' rather than autonomous educators. Negative conditional factors constraining autonomy there include greater school principals' control at the expense of teachers' professional judgement and stricter demands by the state for goal fulfilment and evaluation. Such factors are also evident in England. Greany and Higham (2018) conclude that in England recent policy reforms have sought to move the system away from the original SISS narrative of school-level autonomy and towards MAT-level authority. They see a shift in which the conditions of autonomy for schools are determined increasingly in MATs. The ways in which MATs operate vary. Some are hierarchical in their structure; some more collaborative. A survey of MATs found that a small minority describe themselves as having a single approach to teaching and learning across all academies (less than $8 \%$ ) or as academies having full discretion (less than 20\%): most described their policy as having some consistency between academies as well as encouraging innovation (Cirin 2017: 33). The trend, however, seems to be towards more hierarchical structures, the pressure for this emanating from 'a tighter level of prescription' from central government about how MATs operate and 'a requirement for tight vertical accountability, both within MATs and between MATs and the government' (Greany and Higham 2018: 86). West and Wolfe (2018) examine in detail how the freedoms that were meant to be enjoyed by academies are, for those in MATs, actually in the control of the MAT, not the school. Their stark conclusion is that despite the creation of academies 'having been initially driven by a wish to give schools freedom and autonomy, those (the majority of academies) which are now run by MATs have no freedom - they do not even exist as legal entities to enjoy such freedoms' (p29).

We might hypothesise that in this context negative conditional autonomy will increase for schools and for teachers and others in schools within MATs. The exercise of professional autonomy could become more difficult, though there are likely to continue to be variations between MATs. It is important to recognise too that MATs are only a part of the system, if a significant part which government wishes to expand. Other school groupings, involving academies not in MATs and schools that are still the responsibility of LAs, are constituted in different ways, and there are some schools not in formal groupings, including single academy trusts (SATs) which operate as standalone academies. In these, in some contexts, there may be greater positive conditional autonomy, and the autonomy possible may be used in different ways. There is evidence that types of innovation differ between SATs and academies in MATs. Innovations by SATs - operating as standalone institutions - are more likely to concern school-level operations, such as the curriculum, as compared with academies in MATs where organisation-level innovation, such as reconstituting the governing body, is more likely to have occurred (Cirin 2017: 18-19). 
In the previous section, we noted that there are both conditions external to the educator and conditions internal to the educator, such as professional identity, affecting autonomy. Internal conditions - that is, the factors within schools affecting their autonomy and that of educators- are varied and complex, and hence the distribution of autonomy is likely to constitute a tangled picture. We should be careful not to assume MATs are all characterised by negative conditional autonomy; nor that non-MAT schools are necessarily characterised by positive conditional autonomy.

The degree to which autonomy is regulated raises enormous questions concerning identity and motivations. School leaders and teachers may work to the policies and assessments constructed by central government and national authorities, but this may be the result of considered reflection and choices that they make for themselves. They can be, in other words, the outcome of rational autonomy. Nevertheless, policies and the policy discourse from powerful policy actors can exert a force that seems to require conformity. The 're-regulation' generated by government in creating the current school system in England that Greany and Higham (2018: 23) highlight suggests that there is some degree of regulated autonomy. There are likely to be school leaders and educators, and schools as institutional actors, that adopt purposes and principles through a feeling of compulsion or without reflecting on the strong factors influencing their feelings and thinking.

Competitive pressures on schools are widespread. Greany and Higham's (2018) study found that over $90 \%$ of secondary headteachers in England experience competition. Competitive and performative pressures have consequences for how schools operate and the professional identity of school leaders and teachers. Jeffrey and Troman (2012), for example, observed moves towards more team work, collective working and distributed leadership in schools in England; but they also drew attention to associated changes that arguably distort education, such as a growth in the language and culture of business in schools and a corporate approach focusing on the needs of the institution. School evaluations through the national inspection role of Ofsted exert a strong influence on schools. All schools are graded on the basis of inspections - as 'outstanding', 'good', 'requires improvement' or 'inadequate' (Her Majesty's Chief Inspector of Education, Children's Services and Skills 2017) - and the gradings have implications for schools. For example, following a judgement of 'inadequate', an LA-maintained school has to convert to academy status, whilst for an academy given this grading there may be intervention from a regional school commissioner (Table 1) or the Secretary of State for Education (Roberts and Abreu 2018). For many schools this leads to a constant focus on examination results and preparation for a possible Ofsted inspection (Greany and Higham 2018). Working in such a context creates pressures towards the formation of professional identities that comply with competitive and performative principles. 
If regulated autonomy is a concern, paradoxically it might seem so too is unaccountable autonomy. Upward accountabilities of autonomous schools and MATs to government have been mentioned above. However, the evolving nature of the system can lead to the obscuring of accountability lines. Greany and Higham (2018: 95) conclude that as MATs get larger, the number of managerial levels increases, meaning that LA 'bureaucracy' is replaced by another more complex and less accountable form of bureaucracy. More fundamentally, the creation of academies, whether they are within MATs or not, breaks the accountability connection with LAs and local democratic responsibility for schools. West and Wolfe (2018) explain the ways in which the academies system reduces public accountability and scrutiny. For example, changes to LA-maintained schools have to be a public process, whilst changes to academies and MATs take place in non-public spaces. This can increase the autonomy of some actors in the system, such as leaders of MATs. It contributes to positive conditional autonomy for them. However, autonomy is not an unalloyed good. It carries responsibilities and this requires appropriate processes of accountability. Such processes may be upwards in a hierarchy (within a school, school grouping or to government) or lateral (to colleagues, students and others in a school or school grouping).

In other words, as we noted in the previous section, simply by virtue of being autonomous, the exercise of autonomy is not necessarily ethical. With dependent autonomy, an unreasoned choice is made to follow a source of ethical direction, which could be, for example, policy edicts, subjective feelings of moral rightness or 'consumer' demands. This is not to say that it is wrong to follow these. The characteristic feature of dependent autonomy is the absence of examination of why that is an ethically good source of guidance. Principled autonomy on the other hand is characterised by a reflexive process of examining the principles guiding, or which may be adopted to guide, action so as to ensure that the choices that emerge from them are followable by others and 'universal in scope'. Numbers of schools explicitly seek to develop a culture, practice and professional identities that are not defined predominantly by competitive and performative principles and the systemic pressures they create to follow them. Such schools foster a different approach, valuing creativity, collaboration and identities as educators guided by broader principles of learning (Berry 2016, Sutherland 2017, Woods and Roberts 2018). They seek to exercise principled autonomy within their context and the conditions of autonomy they experience. Planned changes in the inspection framework used by Ofsted may help in creating greater positive conditional autonomy in the curriculum and space for more principled autonomy. From 2019, inspections are intended to focus less intensively on test and examination results and to place more emphasis on the value of a broad, rich curriculum (Her Majesty's Chief Inspector of 
Education, Children's Services and Skills 2018). The impact this has on practice will depend on the final form of the framework and how schools respond.

This chapter is not intended to offer a comprehensive account of the issues involved in ethical autonomy. The consideration of principled autonomy however reinforces the importance of the critical reflexive process which is integral to a philosophy of codevelopment and values clarification underlying collaborative leadership (Woods and Roberts 2018). Such reflexivity is essential to autonomy that has two important characteristics: namely, autonomy that is (a) genuinely self-authored and ethical, and (b) practised with the aims of avoiding unreasoned dependence and deference to unquestioned sources of authority and enhancing critical understanding through collaborative learning. Arguably, the importance of developing principled autonomy that is critically reflexive and aspires to enact principles that apply to all is increased as the varieties of cultures and social structures and their rate of change intensifies in the way described by Archer (2012). The intensified change is characterised by a 'logic of opportunity', as a result of exponentially increasing innovation, options and interconnections between ideas, culture, ways of living and working, relationships and so on: the array of increasing choices means that calculating future plans is harder (so rational autonomy is more difficult) and that outcomes need not be zero-sum and the logic of action need not be competitive (Archer 2012: 35). To make choices that have some considered moral basis requires development as 'a social individual, which develops through processes of individual and relational learning over time: it is about learning how and in what direction to develop one's own individuality and one's own social identity and practice, learning with and from, as well as contributing to the wellbeing of, others' - that is relational freedom in which 'the person is able to arrive at their own decisions informed by a considered awareness of themselves and the context of which they are part - including its opportunities, resources, constraints and ethical demands.' (Woods and Roberts 2018: 69).

\section{CONCLUSIONS}

In this chapter we have provided an overview of the development of the school system in England since 2010. As matters stand at the time of writing, the policy intention is that the numbers of 'independent' state schools - academies - will increase, and that most academies will be part of a MAT. How far this will progress and at what rate is difficult to forecast. The evolving system and the challenges of a middle tier, between national authorities and schools, comprising MATs, LAs and other groupings of schools take educational policy into unchartered territory. By January 2018, although the proportion of schools that were academies had increased significantly since 2010, almost two-thirds of schools continued to be classed as maintained and the responsibility of LAs (National 
Audit Office 2018). This means that two systems of schools - academies and maintained schools - co-exist within the English school system. Whether this continues depends not only on the decisions and actions of numerous national authorities and other institutional actors in the system, but also on future governments and if there are radical changes in policy direction.

The discussion in this chapter focused on an exploration of autonomy in order to contribute to a critical understanding of the developing school system in England. Issues key to such a critical understanding are:

1. The distribution of autonomy. Some institutions, positions of authority and individuals have more autonomy than others. A variety of internal and external variables (resources, opportunities, relationships and so on) work to produce conditional autonomy that is positive or negative in its fostering of freedoms, depending on the mix of variables affecting the institution, position or individual concerned. The degree to which 'autonomous academies', as a result of their licensed autonomy, are free and result in real freedoms for their leaders and teachers is a major issue. Significant degrees of autonomy cannot be presumed to follow from the policy emphasis on autonomy.

2. The delusion of regulated autonomy. Where there is a tight system of regulation and a coercive discourse demanding the adoption of certain identities and principles, without encouraging critical reflexivity, there are compelling influences giving rise to regulated autonomy. This means educational leaders, teachers and others, and institutions, adopting purposes and principles through compulsion or without reflecting on the strong factors influencing their feelings and thinking. In essence, where there is such regulated autonomy there is not really autonomy.

3. The ethics of autonomy. Exploring the meaning of ethical autonomy helps in appreciating the moral demands entailed in autonomy. Making an unreasoned choice to follow a source of ethical direction - be it a national policy directive, subjective feelings of moral rightness or 'consumer' demands - is better characterised as dependent autonomy. Exercising rational autonomy, so that choices concerning how to act or determine institutional policy are reasoned and rationally thought through, does not in itself make those choices ethical.

Something more is required. This leads to an argument for principled autonomy characterised by critical reflexivity. Essential to principled autonomy is a process of examining the principles guiding, or which may be adopted to guide, action so as to ensure that the choices that emerge from them are ones that we consider are justifiable and morally worthy for everyone to choose. The principles are in this sense universal in scope. 
4. Principled autonomy and social justice. The aspiration in principled autonomy to principles that are universal in scope gives a presumption of responsibility beyond the interests of the self or to one institution or group. If such a principle is expressed as 'do as one would be done by' - which, arguably, is a neat expression of what justifiably all can be expected ethically to follow - responsibility extends to working for the welfare and best interests of others. Autonomy then, to be ethical, needs to be energised by this kind of principle and thus predisposed to action that challenges systemic inequalities in school, local and system-wide practices. There are difficulties and risks in doing this in a system that assesses performance on the basis of narrow measures of measurable success. Yet creative modifications to practice generated by teachers and others collaboratively 'constant little improvisations' (Hargreaves 2012: 26) - can lead to significant reconfigurations at the level of a whole school or school grouping. Where constant improvisations are motivated by principled autonomy, advancing social justice can become a feature of the self-improving system.

We suggest that these four issues and the related notions of autonomy explored in this chapter offer a framework for examining the practical operation of autonomy and evolving nature of the school system in England.

\section{REFERENCES}

Academies Commission (2013) Unleashing Greatness: Getting the best from an academised system - The Report of the Academies Commission, London: RSA/ Pearson. Available at: https://www.thersa.org/discover/publications-and-articles/ reports/unleashing-greatness-getting-the-best-from-an-academised-system

Andrews, J. and Perera, N., with Eyles et al. (2017) The impact of academies on educational outcomes, London: Education Policy Institute.

Apple, M.W. (2007). Whose markets, whose knowledge? In A.R. Sadovnik (Ed.), Sociology of education. A critical reader. New York: Routledge.

Archer, M. (2012) The Reflexive Imperative, Cambridge: Cambridge University Press.

Baggini, J. (2015) Freedom Regained: The Possibility of Free Will. London: Granta.

Berry, J. (2016) Teachers Undefeated: How global education reform has failed to crush the spirit of educators, London: UCL Institute of Education.

Bolton, P. (2015) Converter Aacdemies: Statistics, Briefing Paper: Number 6233, London: House of Commons Library.

Boyask, R. (2015) Nuanced understandings of privatization in local authorities' services to schools, Management in Education, 29(1): 35-40. 
Chapman, C. (2015). From one school to many: Reflections on the impact and nature of school federations and chains in England. Educational Management Administration \& Leadership, 43(1), 46-60.

Clegg, N., Allen, R., Fernades, S., Freedman, S. and Kinnock, S. (2017), Commission on Inequality in Education, London: Social Market Foundation.

Cirin, R. (2017) Academy trust survey 2017: Research report, London: DfE.

DfE (2016a) Educational Excellence Everywhere, London: DfE.

DfE (2016b) DfE strategy 2015-2020 World-class education and care, London: DfE.

Fielding, M, Bragg, S, Craig, J, Cunningham, I, Eraut, M, Gillinson, S, Horne, M, Robinson, C \& Thorp, J, (2005) Factors Influencing the Transfer of Good Practice, Nottingham, DfES Publications.

Gorard, S. (2014) The link between Academies in England, pupil outcomes and local patterns of socio-economic segregation between schools, Research Papers in Education, 29:3, 268-284

Gorard, S. (2016) The complex determinants of school intake characteristics and segregation, England 1989 to 2014, Cambridge Journal of Education, 46(1): 131146.

Greany, T. and Higham, R. (2018) Hierarchy, markets and Networks: Analysing the 'selfimproving school-led system' agenda in England and the implications for schools, London: UCL Institute of Education Press.

Gu, Q., Rea, S., Smethem, L., Dunford, J., Varley, M. and Sammons, P. (2015) Teaching Schools Evaluation: Final Report, Nottingham: National College for Teaching and Leadership.

Hargreaves, D. H. (2010) Creating a self-improving system, Nottingham: National College for School Leadership.

Hargreaves, D. H. (2011) Leading a self-improving system, Nottingham: National College for School Leadership.

Hargreaves, D. H. (2012) A self-improving school system: towards maturity, Nottingham: National College for School Leadership.

Hargreaves, D. H. (2014) A self-improving school system and its potential for reducing inequality, Oxford Review of Education, 40(6): 696-714.

Her Majesty's Chief Inspector of Education, Children's Services and Skills (2017) The Annual Report of Her Majesty's Chief Inspector of Education, Children's Services and Skills 2016/17, London: Ofsted.

Her Majesty's Chief Inspector of Education, Children's Services and Skills (2018) HMCI commentary: curriculum and the new education inspection framework, Available at https://www.gov.uk/government/speeches/hmci-commentary-curriculum-and-thenew-education-inspection-framework 
Hill, R. (2011) The importance of teaching and the role of system leadership: A commentary on the Illuminas research for the National College, Nottingham, National College for School Leadership.

Hill, V. (2014) The HertsCam TLDW programme, in D. Frost (ed.) Transforming Education through Teacher Leadership. Cambridge: Leadership for Learning/The Cambridge Network.

House of Commons Education Committee (2017) Multi-academy trusts, Seventh report of Session 2016-2017, London: House of Commons.

Jeffrey, B. and Troman, G. (2012) The performative institutional embrace, Journal of Organizational Ethnography, 1(2): 195-212.

Lumby, J. and Coleman, M. (2016) Leading for Equality: Making Schools Fairer. London: Sage.

Lundström, U. (2015) Teacher autonomy in the era of New Public Management, Nordic Journal of Studies in Educational Policy, 1: 73-85.

Murphy, R. (1982) Power and Autonomy in the Sociology of Education, Theory and Society, Vol. 11, No. 2, pp. 179-203

National Audit Office (2018) Converting maintained schools to academies, London: National Audit Office.

National College for Teaching and Leadership (2017) Teaching School Alliances: Key Information Form (KIF) 2015/16 - Analysis, London: Department for Education.

Nerys, R. (2017) FAQs: Academies and free schools, Briefing Paper: Number 07059, London: House of Commons Library.

O’Neill, O. (2003) Autonomy: The Emperor's New Clothes, Aristotelian Society Supplementary Volume, Volume 77, Issue 1, Pages 1-21.

PricewaterhouseCoopers (2008) Academies Evaluation: Fifth Annual Report, London: Department for Children, Schools and Families.

Reay, D. (2017) Miseducation: Inequality, education and the working classes, Bristol: Policy Press.

Roberts, N. (2017) FAQs: Academies and free schools, Briefing Paper: Number 07059, London: House of Commons Library.

Roberts and Abreu (2018) School inspections in England: Ofsted, Briefing Paper: Number 07091, London: House of Commons Library.

Solbrekke, T. \& Sugrue, C. (2011) Professional responsibility - back to the future, in C. Sugrue \& T. Solbrekke (Eds.) Professional Responsibility: New Horizons of Praxis Abingdon: Routledge pp11-28

Stacey, R. (2012) Tools and Techniques of Leadership and Management: Meeting the Challenge of Complexity. London: Routledge.

Sutherland, T. (2017) Organisational strategies to multiply the teacher leadership effect, in D. Frost (ed.) Empowering Teachers as Agents of Change: A Non-positional Approach to Teacher Leadership. Cambridge: Leadership for Learning. 
Szegedi, E. (ed) et al (2018) Guide for facilitators of collaborative teacher learning, Ebook, EFFeCT Project, available at http://effect.tka.hu/methodological-framework.

Wenger, E. (1998) Communities of Practice. Cambridge: Cambridge University Press.

West, A. and Bailey, E. (2013): The Development of the Academies Programme: 'Privatising' School-Based Education in England 1986-2013, British Journal of Educational Studies, 61 (2): 137-159.

West, A. and Wolfe, D. (2018) Academies, the School System in England and a Vision for the Future, Clare Market Papers No. 23, London: LSE Academic Publishing.

Wolfe, D. (2013) Schools: The Legal Structures, the Accidents of History and the Legacies of Timing and Circumstance, Education Law Journal, 14 (2): 100-113.

Woods P. A. (2013) Sense of purpose: reconfiguring entrepreneurialism in public education. In: Slater CL and Nelson S (eds) Understanding the Principalship: An International Guide to Principal Preparation. Bingley: Emerald.

Woods, P. A. (2016) Democratic roots: feeding the multiple dimensions of 'leadership-aspractice', in J. Raelin (ed.), Leadership-as-Practice: Theory and Application, London: Routledge.

Woods, P. A. and Roberts, A. (2014) 'The New Executives in a Landscape of Change: The Emerging Reality of Plural Controlled Schooling', in A. Nir (ed) The School Superintendent: An international perspective, New York: Nova Science Publishers.

Woods, P. A. and Roberts, A. (2018) Collaborative School Leadership: A critical guide, London: SAGE.

Woods, P. A. and Simkins, T. (2014) 'Understanding the Local: Themes and issues in the experience of structural reform in England', Educational Management Administration \& Leadership, 42 (3): 324-340.

Woods, P.A., Roberts, A. and Chivers, L. (2016) Collaborative Teacher Learning: Cases from the HertsCam Network. Hatfield, Hertfordshire: Centre for Educational Leadership, School of Education, University of Hertfordshire. 